\title{
Sport of Policy Analysis and Evaluation: a Systematic Literature
} Review

\author{
Muhlisin $^{1)}$, Sandey Tantra Paramitha ${ }^{2)}$, Yudhi Purnama ${ }^{3)}$, Rif'iy \\ Qomarullah $^{4)}$, Muhammad Gilang Ramadhan ${ }^{5)}$ \\ ${ }^{1}$ Pendidikan Olahraga, Sekolah Pascasarjana, Universitas Pendidikan Indonesia \\ ${ }^{2}$ Ilmu Keolahragaan FPOK Universitas Pendidikan Indonesia \\ ${ }^{3}$ PJKR FKIP Universitas Wahid Hasyim, Indonesia \\ ${ }^{4}$ Pendidikan Jasmani Kesehatan \& Rekreasi, FIK Universitas Cendrawasih, Indonesia \\ ${ }^{5}$ Pendidikan Olahraga, Sekolah Pascasarjana, Universitas Pendidikan Indonesia \\ Email: ${ }^{1}$ muchlisin@unwahas.ac.id, ${ }^{2}$ sandeytantra18@upi.edu, ${ }^{3}$ yudhipurnama@unwahas.ac.id, \\ 4qomarrifqi77@gmail.com, ${ }^{5}$ gilangramadhan16@upi.edu,
}

\begin{abstract}
The research is based on the lack of research and publications related to macro sports policy in Indonesia. Therefore, the purpose of this paper is to analyze research articles related to sports policy in Indonesia. This study uses a systematic literature review (SLR). The research population uses research articles related to sports policy and the research sample uses the purposive sampling technique using inclusive and exclusive criteria. The results of this study indicate that the direction of sports policy in Indonesia is still leading to achievement sports that focus on the development of the sport itself. It can be concluded that sport has not been able to become an important aspect in wider development (development through sport) and the results of the Literature Review, it can be concluded that the Evaluation Analysis of sports policy is still very minimal.
\end{abstract}

Key Words: Analysis, Evaluation, Sports Policy

\section{Analisis dan Evaluasi Kebijakan Olahraga : a Systematic Literature Review}

\begin{abstract}
ABSTRAK
Penelitian didasari dari minimnya jenis penelitian dan publikasi berkaitan dengan kebijakan olahraga secara makro di Indonesia. Untuk itu tujuan dari penulisan ini adalah untuk menganalisis artikel penelitian berkaitan dengan kebijakan olahraga di Indonesia. Penelitian ini menggunakan penelitian a Systematic literature review (SLR). Populasi penelitian menggunakan artikel-artikel penelitian berkaitan dengan kebijakan olahraga dan sampel penelitian menggunakan Teknik Purposive Sampling menggunakan kriteria inklusif dan Eksklusif. Hasil dari penelitian ini bahwa arah kebijakan olahraga di Indonesia masih mengarah pada olahraga prestasi yang fokus pada pengembangan olahraga itu sendiri. Hal ini dapat disimpulkan bahwa olahraga belum bisa menjadi aspek penting dalam pembangunan yang lebih luas (development through sport) dan Hasil Review Literature dapat disimpulkan bahwa Analisis Evaluasi kebijakan olahraga masih sangat minim.
\end{abstract}

Kata Kunci: Analisis, Evaluasi, Kebijakan Olahraga

Info Artikel

Dikirim : 24 September 2021

Diterima : 12 November 2021

Dipublikasikan : 30 November 2021
(C) 2021 IKIP BUDI UTOMO MALANG

P-ISSN 2613-9421

E-ISSN 2654-8003

\footnotetext{
Alamat korespondensi: yudhipurnama@unwahas.ac.id

Universitas Wahid Hasyim, J1. Menoreh Tengah X No.22, Sampangan, Kec. Gajahmungkur, Kota Semarang, Jawa Tengah 50232, Indonesia
} 


\section{PENDAHULUAN}

Sebuah ilmu sosial terapan yang menggunakan berbagai metode dan Teknik dalam memunculkan berbagai informasi yang ada kaitanya dengan kebijakan adalah pengertian dari analisis kebijakan. Namun banyak pemimpin yang tidak mengetahui bahwa pentingnya dilakukan analisis kebijakan. (Safitri et al., 2021). Kebijakan sebuah negara dalam upaya membangun olahraga adalah salah satu dari pilar yang bertujuan menjaga kesehatan dan kebugaran jiwa dan raga yang bisa memberikan dukungan pada produktivitas sumber daya manusia.(Rahadian $\&$ Ma'mun, 2018). Meskipun sebagai ilmu terapan kebijakan sangat erat kaitannya dengan berbagai bidang yang berkaitan dengan tata Kelola seperti pada bidang keolahragaan.

Pembuat kebijakan olahraga dapat membuat perubahan kebijakan olahraga yang akan memiliki efek yang relatif cepat pada peningkatan kinerja atlet. Kebijakan dan proses olahraga yang dipertimbangkan dan diterapkan dengan baik dapat memengaruhi hasil kinerja jangka panjang. Selama 20 tahun terakhir, berbagai penelitian telah melihat faktor-faktor di tingkat meso yang mempengaruhi kinerja olahraga negara-negara (Gowthorpb et al., 2014) Isu teoretis muncul karena masih belum jelas sejauh mana kebijakan elit olahraga dapat mempengaruhi keberhasilan suatu bangsa di kompetisi internasional besar. Ada berbagai penelitian, yang menunjukkan bahwa faktor tingkat makro - di mana populasi dan kekayaan diidentifikasi sebagai yang paling penting - " menjelaskan " lebih dari 50\% kesuksesan olahraga internasional. Pemerintah menjadi lebih bersedia untuk campur tangan secara langsung dalam pengembangan olahraga elit dengan melakukan investasi keuangan yang cukup besar, sehingga mengarah pada peningkatan pelembagaan sistem olahraga elit (De Bosscher et al., 2009) Kebijakan olahraga telah menjadi motor sejumlah perubahan cepat dan pergeseran prioritas aspek pembangunan nasional (Collins, 2010)

Mengacu pada UU No. 25 tahun 2004 tentang Sistem Perencanaan Pembangunan Nasional, perencanaan pembangunan dilakukan ke dalam tiga tahap, yaitu perencanaan jangka pendek, jangka menengah dan jangka panjang. Perencanaan jangka panjang dirumuskan dalam dokumen Rencana Pembangunan 
Jangka Panjang Nasional (RPJPN) tahun 2005-2025) Olahraga masih belum menunjukkan bahwa olahraga menjadi arus utama dalam sistem perencanaan pembangunan nasional. Secara umum hadirnya sistem pembangunan keolahragaan nasional akan sangat dipengaruhi oleh bagaimana Sistem Perencanaan Pembangunan Nasional. karena dari situlah pandangan dan ideologi negara memandang bagaimana pentingnya olahraga dalam pembangunan nasional.

Olahraga elit saat ini menikmati investasi tingkat tinggi di banyak negara kapitalis. Tujuan utama dari pengembangan olahraga elit adalah untuk mengenalkan dan memberikan alasan kepada negara untuk memprioritaskan dan berinvestasi dalam olahraga elit (Grix \& Carmichael, 2012). Banyak negara maju yang justru sekarang ini memanfaatkan olahraga sebagai investasi dalam Sistem pembangunan Nasional mereka. Hal ini tentu menjadi landasan strategis kajian bagaimana mengembangkan arah kebijakan olahraga baik secara mikro maupun makro dalam tatanan pembangunan olahraga di Indonesia.

Arah pembangunan keolahragaan nasional saat ini berpusat pada orientasi pencapaian prestasi di berbagai tingkatan. Banyak pemangku kebijakan keolahragaan banyak menentukan prioritas arah kebijakan mengarah pada prestasi. Menjadikan tolak ukur prestasi sebagai arah penentuan kebijakan. Hal ini sangat memerlukan kajian dan analisis mendalam berkaitan dengan kebijakan olahraga di tingkat makro maupun mikro di Indonesia. Tentu ketimpangan dari tidak berimbangnya 3 pilar pengembangan tersebut akan berdampak pada pengembangan olahraga itu sendiri ketika ada 1 pilar yang terlalu dianggap penting sedangkan pilar lainnya banyak diabaikan dan tidak diperhatikan. Maka menjadi penting kajian kebijakan olahraga dapat menyelaraskan dan menyeimbangkan ketiga pilar pembangunan olahraga nasional.

Olahraga pendidikan, olahraga rekreasi, dan olahraga prestasi adalah cakupan dari pembangunan olahraga. Ketiga ruang lingkup olahraga ini dilakukan melalui pembinaan dan pengembangan olahraga secara terencana, sistematik, berjenjang, dan berkelanjutan, yang dimulai dari pembudayaan dengan pengenalan gerak pada usia dini, pemassalan dengan menjadikan olahraga sebagai gaya hidup, pembibitan dengan penelusuran bakat dan pemberdayaan sentra- 
sentra keolahragaan melalui sistem kompetisi, serta peningkatan prestasi dengan pembinaan olahraga unggulan nasional sehingga olahragawan andalan dapat meraih puncak pencapaian prestasi.(Rahadian \& Ma'mun, 2018).

Belum adanya penelitian dan kajian mengenai 3 pilar keolahragaan yang berkaitan dengan anggaran, program dan perhatian pemerintah sehingga diperlukan kajian-kajian dan penelitian yang berkaitan dengan kebijakan keolahragaan. Maka berdasarkan kajian diatas penulis menganalisa minimnya jenis penelitian dan publikasi berkaitan dengan kebijakan olahraga secara makro di Indonesia. Untuk itu tujuan dari penulisan ini adalah untuk mengexplorasi artikel penelitian berkaitan dengan kebijakan olahraga di Indonesia. Hal ini diharapkan dapat menjadi referensi kajian dan analisis kebijakan olahraga di masa yang akan datang.

\section{METODE}

Penelitian ini menggunakan penelitian a Systematic literature review (SLR). Literatur review dibatasi dengan kriteria artikel yang mengkaji tentang analisis, evaluasi, kajian kebijakan olahraga dari 3 pilar yaitu olahraga prestasi, olahraga masyarakat dan olahraga Pendidikan pada jurnal yang diterbitkan selama tahun 2020 s.d 2021. Artikel dalam literature review ini dilakukan dengan cara menganalisis, mengekstrasi dan mensintesis kemudian hasilnya dirangkum berkaitan dengan kebijakan olahraga.

Artikel desain penelitian SLR dengan menggunakan mesin pencarian secara acak dengan menelusuri hasil penelitian kebijakan Olahraga berbahasa indonesia. Artikel yang digunakan difokuskan pada artikel original empirical research atau artikel penelitian yang berisi hasil dari pengamatan aktual kajian maupun analisis dimana terdapat abstrak, pendahuluan, metode, hasil, dan diskusi

Strategi pencarian artikel menggunakan database yang tersedia pada google scholar, Portal Garuda dan Microsoft Academic. Kata kunci dalam menemukan artikel, yaitu kebijakan Olahraga, Evaluasi Kebijakan Olahraga, Analisis Kebijakan Olahraga. Peneliti menggunakan “AND” sebagai Boolean operator. Penggunaan boolean operator "AND” bertujuan untuk mengkombinasikan konsep 
dan aspek yang berbeda sebagai kata kunci pencarian sehingga mempersempit dokumen yang akan didapat.

Dari hasil analisis diharapkan akan ditemukan sebuah kesimpulan yang dapat dijadikan dasar mengenai kebijakan olahraga. Tabulasi data dari hasil artikel kemudian disitasi dan dianalisis dan dibahas secara mendalam dalam artikel ini.

\section{HASIL}

Berdasarkan penelusuran artikel dengan menggunakan google scholar dan portal garuda diperoleh beberapa artikel yang relevan dan sesuai dengan kriteria inklusi diperoleh sebanyak 20 artikel dan yang layak di Analisa sebanyak 7 Artikel berkaitan dengan Kebijakan Olahraga.

Tabel 1. Hasil rekapitulasi Literatur Review

\begin{tabular}{lccc}
\hline \multirow{2}{*}{ Keterangan } & \multicolumn{3}{c}{ Hasil Penelusuran } \\
\cline { 2 - 4 } & $\begin{array}{c}\text { Google } \\
\text { Scholar }\end{array}$ & $\begin{array}{c}\text { Portal } \\
\text { Garuda }\end{array}$ & $\begin{array}{c}\text { Microsoft } \\
\text { Academic }\end{array}$ \\
Penelusuran Lengkap & 15.600 & 4 & 3.363 \\
Sesuai Kriteria Inklusi & 11 & 3 & 6 \\
Layak untuk dianalisa & 6 & 0 & 1 \\
\hline
\end{tabular}

Terdapat 7 jenis artikel yang dapat dianalisis dari beragam jenis penelitian berkaitan dengan kebijakan olahraga mencakup kebijakan secara nasional maupun dalam lingkup mikro. Dari kata kunci yang digunakan, artikel kebijakan tidak sebanyak artikel manajemen, bidang kajian yang lebih umum dari kebijakan namun keduanya memiliki kemiripan dalam pemahaman di masyarakat. Artikel dengan kata kunci manajemen cenderung lebih banyak dibandingkan dengan artikel kebijakan. Hal ini menunjukkan perlu banyak kajian-kajian atau penelitian yang mengkaji berkaitan dengan kebijakan khususnya bidang olahraga.

Berikut hasil secara detail artikel hasil penelurusan menggunakan a Systematic Literature review tentang kebijakan olahraga. Tabel 2. Hasil Penyaringan Artikel yang layak di analisis

\begin{tabular}{clllll}
\hline NO & Peneliti / Tahun & Judul Artikel & \multicolumn{2}{c}{ Hasil/Temuan } \\
\hline 1 & (Safitri & et & al., & Urgensi Analisis & Analisis kebijakan merupakan sebuah \\
& 2021) & & Kebijakan & ilmu sosial terapan yang menggunakan \\
& & & & berbagai teknik dan metode dalam \\
& & & & melahirkan informasi-informasi yang \\
& & & & berhubungan dengan kebijakan. Analisis \\
& & & & kebijakan ini sangat penting untuk \\
& & & & dilaksanakan. & Alasan yang mendasari diperlukannya
\end{tabular}




\begin{tabular}{|c|c|c|c|}
\hline & & & $\begin{array}{l}\text { analisis kebijakan yaitu untuk } \\
\text { mengetahui segala bentuk kelayakan dan } \\
\text { pembiayaan dari kebijakan yang diambil } \\
\text { yang dianalisis melalui proses ilmiah } \\
\text { dengan pendekatan saintifik. Dengan } \\
\text { diketahuinya kelayakan sebuah kebijakan } \\
\text { maka dapat dijadikan pertimbangan } \\
\text { dalam melahirkan kebijakan tersebut dan } \\
\text { dengan diketahuinya pembiayaan maka } \\
\text { dapai disusun secara strategis dan efektif } \\
\text { pengeluaran yang akan digunakan. }\end{array}$ \\
\hline 2 & $\begin{array}{l}\text { (Ramadhan et } \\
\text { al., 2020) }\end{array}$ & $\begin{array}{l}\text { Implementasi } \\
\text { Kebijakan } \\
\text { Olahraga } \\
\text { Pendidikan } \\
\text { Sebagai Upaya } \\
\text { Pembangunan } \\
\text { Melalui Olahraga } \\
\text { Berdasarkan } \\
\text { Undang-Undang } \\
\text { Sistem } \\
\text { Keolahragaan } \\
\text { Nasional }\end{array}$ & $\begin{array}{l}\text { Hasil dari penelitian ini ditemukan } \\
\text { bahwa implementasi kebijakan pada } \\
\text { olahraga Pendidikan sudah sesuai dengan } \\
\text { Undang-undang sistem keolahragaan } \\
\text { nasional. Namun masih terdapat } \\
\text { kekurangan serta ketidakmerataan pada } \\
\text { beberapa aspek. Penelitian ini merupakan } \\
\text { kebaruan dalam studi analisis kebijakan } \\
\text { olahraga di Indonesia khususnya di Kota } \\
\text { Bandung. }\end{array}$ \\
\hline 3 & $\begin{array}{l}\text { (Indrawan } \& \\
\text { Riyoko, 2020) }\end{array}$ & $\begin{array}{l}\text { Kebijakan } \\
\text { Dispora Kota } \\
\text { Palembang } \\
\text { Dalam } \\
\text { Megembangkan } \\
\text { Minat } \\
\text { Masyarakat } \\
\text { Untuk } \\
\text { Berolahraga }\end{array}$ & $\begin{array}{l}\text { Hasil penelitian menunjukkan bahwa } \\
\text { sejauh ini Dinas Pemuda dan Olahraga } \\
\text { Kota Palembang telah berupaya } \\
\text { semaksimal mungkin dalam membuat } \\
\text { suatu kebijakan dan mewujudkan suatu } \\
\text { pembinaan olahraga dengan baik dan } \\
\text { menyeluruh kepada masyarakat, } \\
\text { tujuannya untuk memudahkan setiap } \\
\text { warga masyarakat yang ingin melakukan } \\
\text { aktivitas olahraga dan mendapatkan } \\
\text { pelayanan pembinaan olahraga secara } \\
\text { menyeluruh terhadap semua fasilitas } \\
\text { olahraga di kota Palembang. faktor } \\
\text { pendukung dengan adanya pembinaan } \\
\text { olahraga telah disediakan sarana dan } \\
\text { prasarana olahraga yang memadai, faktor } \\
\text { penghambatnya sendiri masih minimnya } \\
\text { masyarakat yang mengerti pentingnya } \\
\text { olahraga bagi kesehatan dan kebugaran } \\
\text { tubuh, dan tanggapan masyarakat sendiri } \\
\text { masyarakat senang karena merasa } \\
\text { diperhatikan dengan adanya pembinaan } \\
\text { olahraga dimasyarakat yang telah }\end{array}$ \\
\hline
\end{tabular}




\begin{tabular}{|c|c|c|c|}
\hline & & & $\begin{array}{l}\text { direncanakan oleh } \text { Dispora } \\
\text { Palembang. }\end{array}$ \\
\hline 4 & $\begin{array}{l}\text { (Kusumiadi } \\
\text { al., 2021) }\end{array}$ & 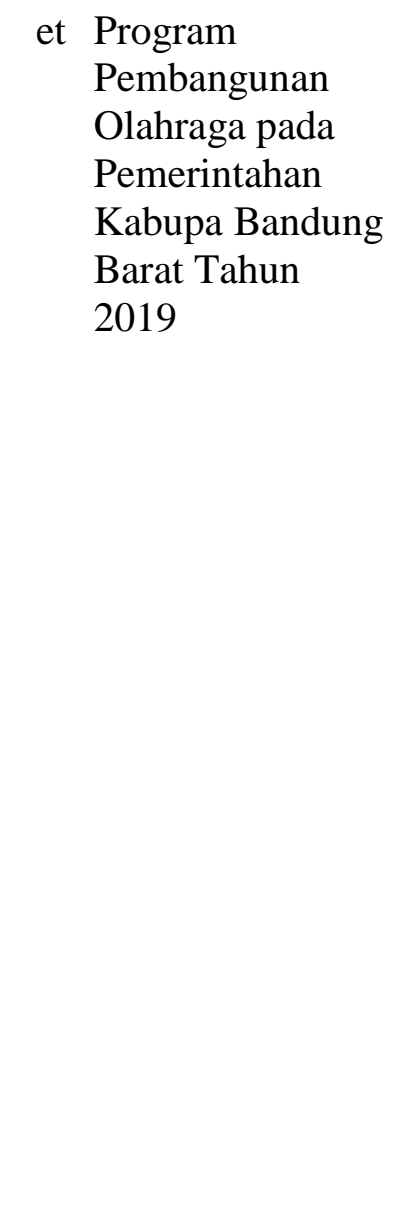 & $\begin{array}{l}\text { 1. program pembangunan olahraga di } \\
\text { Kabupaten Bandung Barat sudah } \\
\text { cukup baik, melihat dari hasil } \\
\text { wawancara yang telah disebutkan. } \\
\text { Wawancara pun dilakukan dengan } \\
\text { orang-orang yang dapat dipercaya } \\
\text { keabsahan datanya. Hasil dari } \\
\text { penelitian terhadap informan di } \\
\text { lapangan pun membuahkan hasil } \\
\text { bahwa program dan kebijakan di } \\
\text { Bandung Barat sudah cukup untuk } \\
\text { mendukung masyarakat dalam } \\
\text { melakukan aktifitas olahraga. Namun } \\
\text { berdasarkan keterangan informan } \\
\text { juga, sebaiknya untuk tahun anggaran } \\
\text { 2. kedepannya, program pemberian alat- } \\
\text { alat untuk masyarakat harus lebih } \\
\text { akurat lagi. Karena ada masyarakat } \\
\text { yang suda hmelakukan pengajuan } \\
\text { proposal lebih dahulu tapi kalah } \\
\text { dengan yang baru memasukan ajuan } \\
\text { untuk pengadaan alat-alat tersebut. } \\
\text { Oleh karena itu ada baiknya lebih } \\
\text { ditingkatkan lagi dalam hal pelayanan } \\
\text { terhadap masyarakatnya. }\end{array}$ \\
\hline 5 & $\begin{array}{l}\text { (Sirait et } \\
\text { 2021) }\end{array}$ & $\begin{array}{l}\text { al., Implementasi } \\
\text { kebijakan } \\
\text { keolahragaan dan } \\
\text { peran pemangku } \\
\text { kepentingan } \\
\text { dalam } \\
\text { peningkatan } \\
\text { prestasi atlet }\end{array}$ & $\begin{array}{l}\text { 1. peningkatan prestasi atlet tidak bisa } \\
\text { dilepaskan dari adanya sinergi dan } \\
\text { kerjasama antara seluruh pemangku } \\
\text { kepentingan, dalam hal ini Dinas } \\
\text { Pemuda dan Olahraga, KONI, } \\
\text { FORMI, atlet, vendor, dan pelatih. } \\
\text { 2. terdapat dua variabel yang sangat } \\
\text { mempengaruhi terhadap peningkatan } \\
\text { atlet berprestasi yaitu Pertama, } \\
\text { sumber daya, di mana ada sumber } \\
\text { daya keuangan/pendanaan dan sumber } \\
\text { daya sarana dan prasarana yang masih } \\
\text { dalam masalah yang belum } \\
\text { terselesaikan } \\
\text { 3. Kedua, sikap para pelaksana, di mana } \\
\text { variabel ini diketahui adanya } \\
\text { stakeholder yang tidak berperan aktif } \\
\text { dikarenakan organisasi tersebut tidak } \\
\text { beroperasi. }\end{array}$ \\
\hline
\end{tabular}




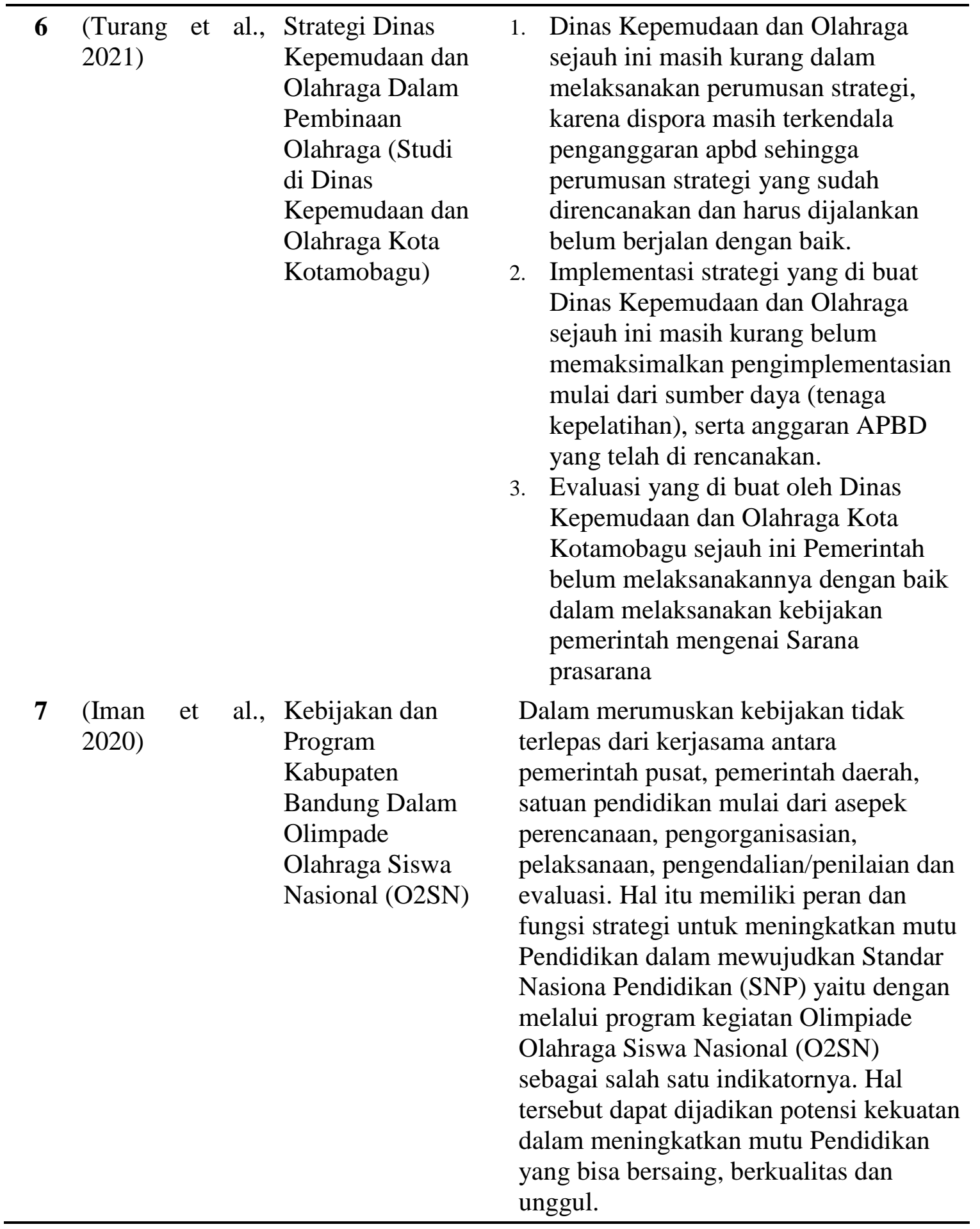

\section{PEMBAHASAN}

Metode a systematic literature review yang mengidentifikasi, menilai, dan menginterpretasi seluruh temuan-temuan pada suatu topik penelitian, untuk menjawab pertanyaan penelitian (research question) yang telah ditetapkan 
sebelumnya (Hayat et al., 2021). Fokus kajian dan pertanyaan penelitian dalam artikel ini menjawab bagaimana arah kebijakan olahraga di Indonesia dan bagaimana evaluasi dan analisis kajian kebijakan yang ada di Indonesia berdasarkan hasil temuan artikel yang temukan.

\section{Kebijakan Olahraga di Indonesia}

Kebijakan olahraga di Indonesia pada dasarnya akan melekat pada arah kebijakan pembangunan nasional yang sudah dituangkan baik dalam RPJP 2005 2025 maupun pada RPJM 5 tahunan yang telah disusun oleh pemerintah. Melihat dari 3 pilar pembangunan keolahragaan seharusnya sistem keolahragaan nasional harus menjadikan ketiga penyangga dalam posisi yang sejajar, sama tinggi sehingga bangunan akan menjadi kokoh. Tidak ada ketiganya yang lebih penting namun ketiganya merupakan unsur yang penting dan saling menopang. Artinya melihat hal tersebut seharusnya 3 pilar olahraga harus menjadi perhatian pemerintah yang memiliki kedudukan sama pentingnya. Jika melihat paradigma kita dapat melihat bagaimana pemerintah, pengampu kebijakan olahraga baik di sektor goverment maupun non goverment masih memandang bahwa pilar olahraga prestasi sebagai pilar utama dalam pembangunan olahraga nasional. Hal tersebut dapat dilihat dari bagaimana anggaran dan perhatian pemerintah yang berlebih pada pilar olahraga prestasi.

Ditinjau dari paradigma pengembangan olahraga "Development Through Sport", yang sekarang ini berkembang seharusnya menjadi pijakan dalam arah kebijakan olahraga. Memposisikan olahraga prestasi dibandingkan dengan pilar yang lainnya, pada dasarnya adalah mengkerdilkan olahraga itu sendiri. Dimana kita terpancang pada bagaimana mengembangkan olahraga. Sudah saatnya kita mulai mengubah paradigma "development of Sport" yaitu bagaimana membangun/mengembangkan olahraga menjadi "Development through Sport" yaitu bagaimana pembangunan nasional disegala bidang melalui olahraga. Hal tersebut tentu akan lebih meningkatkan harkat dan martabat olahraga sebagai "priority sector" atau bidang prioritas dalam pembangunan nasional.

Ada 7 (tujuh) Program Prioritas Nasional yang akan dilakukan sesuai dengan Rencana Pembangunan Jangka Menengah Nasional (RPJMN) Tahun 2020-2024 yang terdiri dari Ketahanan Ekonomi, Pengembangan Wilayah, SDM 
Berkualitas dan Berdaya Saing, Revolusi Mental dan Pembangunan Kebudayaan, Penguatan Infrastruktur, pembangunan lingkungan hidup, serta stabilitas politik hukum dan transformasi pada publik (Bappenas, 2020). Isu utama pembangunan keolahragaan yang Angkat dalam RPJMN tersebut adalah Prestasi olahraga swbagai salah satu indikator daya saing sumber daya mausia di Indonesia. Namun, capaian prestasi olahraga Indonesia masih tertinggal dan belum didukung oleh budaya olahraga yang baik. Pembangunan budaya olahraga perlu ditempuh melalui pemassalan olahraga untuk meningkatkan kesadaran masyarakat dalam meningkatkan kebugaran, kesehatan, dan kegembiraan, serta hubungan sosial.

Ramadhan et al., (2020) dalam artikelnya mengatakan bahwa Sesuai dengan pasal 17 undang-undang sistem keolahragaan, ruang lingkup olahraga dibagi kedalam 3 pilar keolahragaan yaitu Olahraga Pendidikan, olahraga rekreasi dan olahraga prestasi (UU No 3 Tahun 2005, 2005). Paradigma yang ada didalam tata Kelola pembangunan olahraga di Indonesia dapat dilihat masih timpangnya perhatian, pengembangan, pembinaan diantara 3 pilar olahraga tersebut. Baik secara nasional maupun di daerah olahraga prestasi masih menjadi pilar yang paling memeperoleh perhatian yang jauh lebih besar dibandingkan 2 pilar lainnya. Hal ini sebenarnya dapat menjadi kajian Bersama apakah kebijakan pembangunan 3 pilar tersebut memang dirasa sudah tepat atau masih memerlukan kajian secara komprehensif.

Semakin berkembangnya olahraga Pendidikan dan olahraga rekreasi ditandai banyaknya kajian, dan meningkatnya olahraga dikalangan masyarakat melalui even-even olahraga pada lingkup olahraga Pendidikan dan meningkatknya partisipasi masyarakat dalam berolahraga. Untuk membantu pembuat keputusan mendapatkan informasi yang berhubungan dengan keputusan yang akan dibuat maka pelaksanaan analisis kebijakan sangat perlu dilaksanakan. Kegiatan analisis kebijakan tersebut dapat dilakukan melalui kegiatan penelitian, mengklarifikasi dan memisahkan permasalahan yang dapat menemukan ketidaksesuaiakan antara tujuan dan upaya, menyajikan alternatif baru, serta mengusulkan cara untuk menyampaikan ide dalam perumusan kebijakan tersebut.

Kelemahan pada pilar olahraga pendidikan dan olahraga masyarakat/rekreasi adalah masih lemahnya perhatian pemerintah pada 2 pilar tersebut. Stakeholder 
pengampu pada pilar tersebut sebenarnya memiliki ruang lingkup yang luas, namun terkendalanya anggaran. Perhatian pada olahraga prestasi begitu besar, arah kebijakan olahraga masih sangat berorientasi pada olahraga prestasi yang memiliki daya tarik di berbagai kalangan. Tentu hal ini pada dasarnya melemahkan olahraga sendiri, dimana olahraga menjadi alat sarana bagi pengembangan olahraga itu sendiri (Sport Development) Perlu kajian yang mendalam agar bagaimana olahraga dapat menjadi arus utama dalam prioritas pembangunan nasional adalah bagaimana kebijakan olahraga itu sendiri mampu menunjukkan perannya dalam lingkup yang lebih luas, tidak sekedar pengembangan olahraga. Artinya paradigma pengembangan olahraga (Development of Sport) menuju ke pengembangan melalui olahraga (Development throught Sport). Saat ini stakeholder dibidang keolahragaan masih terjebak bagaimana mengembangkan olahraga sehingga terkotak pada bagaimana pencapaian prestasi semata. Hal tersebut yang menjadikan nilai olahraga justru tidak sepenting bidang prioritas dalam pembangunan nasional.

Dalam perspektif historis di Indonesia, kebijakan pengembangan olahraga sangat erat kaitannya dengan visi politik pimpinan negara, yaitu seperti pada era orde lama yang dipimpin oleh Presiden Soekarno, olahraga identik dengan identitas nasional, visi pembangunannya adalah nation and character building, demikian pula pada era orde baru yang dipimpin oleh Presiden Soeharto, olahraga identik dengan kualitas hidup masyarakat suatu bangsa, visi pembangunannya adalah kualitas manusia Indonesia seutuhnya, sedangkan di era reformasi yang sudah dipimpin oleh lima orang presiden, yaitu B.J. Habibie, Abdurachman Wahid, Megawati Soekarnoputri, Susilo Bambang Yudoyono, dan Jokowi, pembangunan olahraga belum ada visi yang jelas, akan tetapi payung hukumnya sudah berhasil ditetapkan, yaitu Undang-undang No. 3 tentang Sistem Keolahragaan Nasional (Ma'mun, 2019).

Dari sisi semangat yang telah dirumuskan dalam Undang-undang No. 3 Tahun 2005 tentang SKN, sesungguhnya Indonesia tidak ketinggalan terlalu jauh jika dibandingkan dengan Negara-negara maju, seperti Korea Selatan dan Jepang, akan tetapi masalah utamanya adalah dalam implementasi Undang-undang dimaksud yang dipandang masih jauh dari yang semestinya (Ma'mun, 2016). Isu 
pergeseran paradigma pembangunan olahraga dari development of sport ke development through sport menginspirasi kembali untuk mengoreksi sesuai dengan isu global pembangunan olahraga yang dicanangkan PBB dengan istilah Sport for Development and Peace (SDP) dalam payung Sustainable Development Goal's (SDG's) untuk tahun pembangunan 2015-2030.

Pembangunan melalui olahraga merupakan isu global yang menjadi paradigma pada bidang olahraga, yang sedang banyak dibahas serta sudah banyak diterapkan di Negara-negara maju, serta memiliki artian bahwa olahraga memiliki peran sebagai salah satu aspek penting dalam hal pembangunan baik tingkat internasional, nasional maupun regional (Cameron, 2018). Hal ini berbeda dengan paradigma 'pengembangan olahraga' yang memiliki artian bahwa olahraga adalah objek yang harus dikembangkan, dan tentunya hanya fokus saja pada olahraganya itu sendiri itu untuk dikembangkan (Dowling et al., 2018).

Pembangunan yang dimaksud merupakan artian pembangunan bidangbidang yang lain yang menjadi indikator dalam pembangunan suatu negara. Salah satunya merujuk pada indikator dari Indeks Pembangunan Manusia (IPM). Pada indikator IPM yang menjadi ukuran yaitu tiga dimensi, yang terdiri dari dimensi umur panjang dan hidup sehat, dimensi pengetahuan, dan dimensi standar hidup layak yang dilihat dari segi ekonomi. Pada dimensi umur panjang dan hidup sehat ini, olahraga akan bisa menjadi aspek yang mempengaruhi pada peningkatan dimensi tersebut. Oleh karena itu, pembangunan dalam arti ini bukan berarti pembangunan yang berarti membangun sebuah benda fisik seperti Gedung dan lainnya. Namun pembangunan yang dimaksud adalah pembangunan yang mengarah pada segala aspek yang menjadi indikator pembangunan secara nasional.

Pentingnya olahraga menjadi aspek pembangunan nasional sejalan dengan salah satu dari tiga dimensi indikator dalam Indeks Pembangunan Manusia (IPM), yaitu umur panjang dan hidup sehat yang diukur dengan angka harapan hidup saat kelahiran (Indeks Kesehatan). Faktanya dengan berolahraga seseorang akan terjaga kondisi kesehatannya, bahkan hingga ketingkat bugar (kondisi diatas sehat). Maka dari itu olahraga akan bisa menjadi aspek penting dari pembangunan nasional suatu Negara, terutama Indonesia yang notabene posisi Indonesia masih 
pada Negara berkembang dilihat dari nilai IPM-nya yaitu 0,689 yang berarti masih pada kelas Negara-negara berkembang.

Dalam rangka pembangunan nasional melalui olahraga ini sangat penting peran dari pemerintah. Pada kapasistasnya pemerintah harus bisa mendorong dan menciptakan masyarakatnya untuk mencapai tahap dimana IPM-nya meningkat hingga masuk pada kelas Negara-negara maju. Salah satu caranya yaitu dengan meningkatkan kondisi kesehatan masyarakatnya, dalam hal ini yaitu dengan membuat masyarakatnya sadar akan pentingnya berolahraga. Maka dari itu pemerintah harus membuat dan tentunya mengimplementasikan aturan-aturan mengenai olahraga dalam rangka membuat masyarakatnya untuk berolahraga sehingga kondisi kesehatannya meningkat. Aturan yang dimaksud dan berlaku di Indonesia sudah tertuang pada Undang-undang no. 3 tahun 2005 tentang Sistem Keolahragaan Nasional. Langkah selanjutnya adalah bagaimana caranya UU no.3 tahun 2005 tentang SKN bisa terimplementasikan dengan baik dan merata di seluruh kawasan Indonesia.

\section{SIMPULAN}

Pada dasarnya kebijakan olahraga di Indonesia saat ini masih mengarah pada paradigma "development of sport/sport development". Artinya bahwa masih menempatkan bahwa olahraga hanya diartikan sebagai olahraga dalam tatanan prestasi olahraga itu sendiri, tanpa melihat manfaat dari olahraga yang bisa berdampak secara lebih luas. Hal ini sangat jelas dibuktikan dengan pengalokasian anggaran yang sangat tidak sebanding dengan ruang lingkup olahraga lain seperti olahraga Pendidikan dan olahraga rekreasi. Maka dari itu merupakan tugas yang sangat luar biasa dan membutuhkan usaha yang sangat besar untuk menjadikan olahraga sebagai aspek penting dalam pembangunan yang lebih luas (development through sport) sesuai amanat yang termaktub pada UU SKN No.3 tahun 2005

\section{DAFTAR RUJUKAN}

Bappenas. (2020). Rencana Pembangunan Jangka Menengah Nasional 2020-2024. National Mid-Term Development Plan 2020-2024, 313.

Cameron, C. (2018). 'Happiness' and 'Holes': Questions for the Future of 
Development through Sport. Canadian Journal of Development Studies / Revue Canadienne d'études Du Développement, 27(4), 567-572. https://doi.org/10.1080/02255189.2006.9669174

Collins, M. (2010). From "sport for good" to "sport for sport's sake" - not a good move for sports development in england? International Journal of Sport Policy, 2(3), 367-379. https://doi.org/10.1080/19406940.2010.519342

De Bosscher, V., De Knop, P., van Bottenburg, M., Shibli, S., \& Bingham, J. (2009). Explaining international sporting success: An international comparison of elite sport systems and policies in six countries. Sport Management Review, 12(3), 113-136. https://doi.org/10.1016/j.smr.2009.01.001

Dowling, M., Brown, P., Legg, D., \& Grix, J. (2018). Deconstructing comparative sport policy analysis: assumptions, challenges, and new directions. International Journal of Sport Policy and Politics, 10(4), 687-704. https://doi.org/10.1080/19406940.2018.1530276

Gowthorpb, L., Gowthorp, L., \& De Bosscher, V. (2014). Elite sport culture and policy interrelationships: the case of Sprint Canoe in Australia. Leisure Studies. https://doi.org/10.1080/02614367.2013.833973

Grix, J., \& Carmichael, F. (2012). Why do governments invest in elite sport? A polemic. International Journal of Sport Policy, 4(1), 73-90. https://doi.org/10.1080/19406940.2011.627358

Hayat, R. S., Mahendra, A., \& Juliante, T. (2021). Analisis Program Structured Terhadap Positive Youth Development dengan Menggunakan Systematic Literature Review dalam Pembelajaran Pendidikan Jasmani dan Olahraga. 20(1), 29-39.

Iman, N., Trisnamansyah, S., \& Arifin, D. (2020). Kebijakan dan Program Kabupaten Bandung Dalam Olimpade Olahraga Siswa Nasional ( O2SN ). Nusantara Education Review, 3(2), 121-132.

Indrawan, Y., \& Riyoko, E. (2020). Kebijakan Dispora Kota Palembang Dalam Megembangkan Minat Masyarakat Untuk Berolahraga. Halaman Olahraga Nusantara (Jurnal Ilmu Keolahragaan), 3(2), 157-172. https://doi.org/10.31851/hon.v3i2.4449

Kusumiadi, Nuryadi, \& ma'mun. (2021). Program Pembangunan Olahraga pada Pemerintahan Kabupaten Bandung Barat Tahun 2019. Jurnal Ilmu Keolahragaan, 19(2), 73-78.

Ma'mun, A. (2016). Pembudayaan Olahraga dalam Perspektif Pembangunan Nasional Konsep, Strategi, dan Implementasi Kebijakan. Sosio Humanika. 
Ma'mun, A. (2019). Governmental Roles in Indonesian Sport Policy: From Past to Present. International Journal of the History of Sport. https://doi.org/10.1080/09523367.2019.1618837

Rahadian, A., \& Ma'mun, A. (2018). Kebijakan Olahraga dalam Pemerintahan Lokal: Sebuah Penelitian dalam Merumuskan Rancangan Induk Pembangunan Olahraga Nasional. Prosiding Seminar Pendidikan JasmaniFPOK UPI, Sport Policy, 1-12. https://doi.org/10.17605/OSF.IO/YZRC8

Ramadhan, M. G., Ma'mun, A., \& Mahendra, A. (2020). Implementasi Kebijakan Olahraga Pendidikan sebagai Upaya Pembangunan Melalui Olahraga Berdasarkan Undang-Undang Sistem Keolahragaan Nasional. Jurnal Terapan Ilmu Keolahragaan. https://doi.org/10.17509/jtikor.v5i1.23824

Safitri, U., Nuarizal, A., \& Gistituati, N. (2021). Urgensi analisis kebijakan. JRTI(Jurnal Riset Tindakan Indonesia), 6(1), 72-76.

Sirait, J., Noer, K. U., Jakarta, U. M., Dahlan, J. K. H. A., Tim, K. C., \& Selatan, T. (2021). Implementasi kebijakan keolahragaan dan peran pemangku kepentingan dalam peningkatan prestasi atlet. Jorpres (Jurnal Olahraga Prestasi), 17(1), 1-10.

Turang, J. G., Sambiran, S., \& Monintja K, D. (2021). Strategi Dinas Kepemudaan dan Olahraga Dalam Pembinaan Olahraga (Studi di Dinas Kepemudaan dan Olahraga Kota Kotamobagu). Jurnal Governance, 1(2), 1-9.

UU No 3 Tahun 2005. (2005). Undang-Undang Republik Indonesia Nomor 3 Tahun 2005 Tentang Sistem Keolahragaan Nasional Dengan. Presiden RI, 1, $1-53$. 